Proceedings

\title{
Determination and Evaluation of Metal Oxide Toxicity on Dermal Fibroblasts by Using the Impedance-Based Assay System ${ }^{+}$
}

\author{
Şükran Şeker ${ }^{1,2}$ \\ 1 Tissue Engineering, Biomaterials and Nanobiotechnology Laboratory, 06100 Ankara, Turkey; \\ sukran.seker@gmail.com \\ 2 Stem Cell Institute, Ankara University, 06520 Ankara, Turkey \\ + Presented at the 2nd International Cell Death Research Congress, Izmir, Turkey, 1-4 November 2018. \\ Published: 5 December 2018
}

\begin{abstract}
Metal oxides have been widely used in various applications such as biomedical, commercial and environmental, due to their unique physicochemical properties. As the use of metal oxides increase worldwide, their exposure to the living systems also increases. It is therefore necessary to understand their potential harmful effects on human and environment health. In this study, dermal fibroblasts were exposed to bulk zinc oxide $(0.1,1,10,50$, and $100 \mu \mathrm{g} / \mathrm{mL})$ for 6 and $48 \mathrm{~h}$. After exposure, changes in cell viability, morphology, membrane damage and zinc oxide uptake were investigated. The response of dermal fibroblasts exposed to different concentrations of bulk zinc oxide was monitored in real-time using an impedance-based assay system. Results demonstrated that zinc oxide at 50 and $100 \mu \mathrm{g} / \mathrm{mL}$ showed significant toxic effects compared to the control cell cultures.
\end{abstract}

Keywords: metal oxide toxicity; impedance-based assay; cell index; dermal fibroblasts; cell response

\section{Introduction}

Zinc oxide is an inorganic compound widely used in the food, cosmetic and pharmaceutical industries. It has been included into polymeric materials to incorporate the antimicrobial and antifungal properties for wound dressings, food packaging and dental filling materials. Also, zinc oxide has been used in various pharmaceutical and cosmetic products due to antibacterial and UV-blocking properties [1]. Some chemical substances can easily be uptaken by the cells and interact with the biological molecules inside the cells affecting a variety of cell responses, leading to the decrease in cell viability, proliferation, etc. [2]. Therefore, the potential toxic effects of such chemicals that directly affect human health need to be comprehensively evaluated.

In recent years, impedance-based high-throughput assay systems are increasingly becoming the preferred system for analyzing the effects of toxic chemical substances on cultured mammalian cells, hence providing information on cell death, proliferation and morphological changes in real time without the use of any labels [3]. This study provides in vitro toxicity data on the responses of dermal fibroblasts cultured with different concentrations of zinc oxide to determine its potential toxic effects using an impedance-based system. 


\section{Materials and Methods}

\subsection{Preparation of Zinc Oxide Dispersions}

Zinc oxide powder (Sigma, St Louis, MO, USA) was exposed to UV irradiation for sterilization for $30 \mathrm{~min}$ before cell culture experiments. The stock solutions of zinc oxide were prepared in cell culture medium and sonicated for $30 \mathrm{~min}$ to form the dispersions. Thereafter, the working solutions $(0.1,1,10,50$, and $100 \mu \mathrm{g} / \mathrm{mL})$ were prepared using cell culture medium from the stock solution.

\subsection{Culture of Dermal Fibroblasts}

Mouse dermal fibroblasts were purchased from ATCC. Frozen cells were thawed in the waterbath at $37{ }^{\circ} \mathrm{C}$ until only a small ice crystal remains. The cells were cultured in DMEM-F12 medium (containing 10\% FBS, $2 \mathrm{mM}$ l-glutamine and 1\% penicillin streptomycin) inside the incubator set to $5 \% \mathrm{CO}_{2}, 37^{\circ} \mathrm{C}$ and $95 \%$ humidity. The cell medium was replaced with fresh medium twice a week.

\subsection{In Vitro Cytotoxicity Assays}

To determine cell viability and membrane damage, in vitro cytotoxicity tests, i.e., MTT (Sigma) and LDH (Sigma) assays, were performed. For that purpose, at $\sim 70-80 \%$ confluence cells were detached from the culture flask (Corning, New York, NY, USA) with trypsin-EDTA solution and seeded onto 96-well plates at a density of $1 \times 10^{4}$ cells per well. After $24 \mathrm{~h}$, the cells were treated with zinc oxide with different concentrations for 6 and $48 \mathrm{~h}$. At specific time point, the cell viability and LDH release were determined using the MTT and LDH kits, respectively.

\subsection{Impedance-Based Measurements}

The responses of dermal fibroblasts cultured with different concentrations of bulk zinc oxide were monitored by the xCELLigence Real-Time Cell Analysis (RTCA) instrument DP (Roche, Basel, Switzerland). After background measurement, the cells were seeded in the wells of electrode plates, cultured inside the incubator and allowed to adhere for $15 \mathrm{~h}$. Then, zinc oxide suspensions were added into each well of the E-plates. The changes in the cell index were continuously monitored for $80 \mathrm{~h}$.

\section{Results and Discussion}

In this study, dermal fibroblast cells were exposed to different concentrations of bulk zinc oxide. The cellular responses to zinc oxide were determined using in vitro toxicity assays (MTT and $\mathrm{LDH})$, as well as by the xCELLigence Real-Time Cell Analyzer system. The changes in the morphology of cells exposed to zinc oxide were monitored using inverted microscopy. The results showed that the cells exposed to 50 and $100 \mu \mathrm{g} / \mathrm{mL}$ zinc oxide gradually lost their characteristic phenotype, started to shrink and obtained irregular shapes (Figure 1).
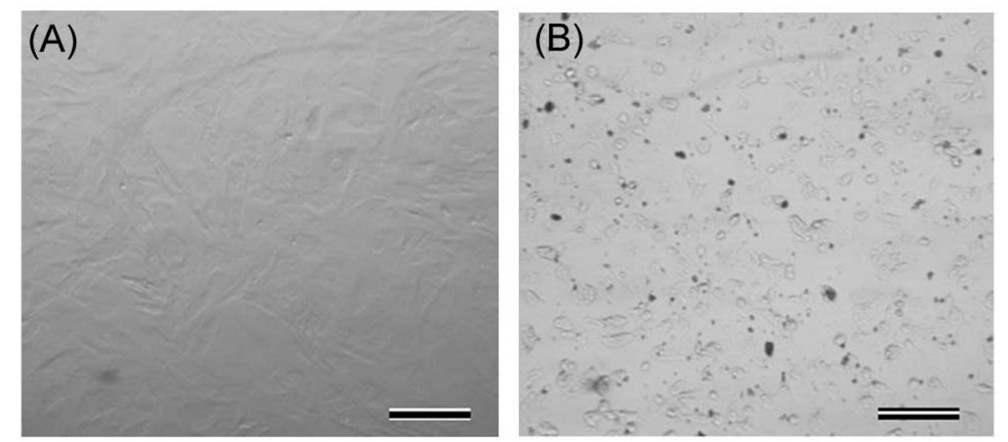

Figure 1. Representative phase contrast microscopy images demonstrating control (A) and 100 $\mu \mathrm{g} / \mathrm{mL}$ zinc oxide-treated cells (B). Scale bars: $100 \mu \mathrm{m}$. 
In vitro toxicity assay showed that zinc oxide caused significant decrease in cell viability and significant increase in LDH release at $50-100 \mu \mathrm{g} / \mathrm{mL}$ for $48 \mathrm{~h}$ (Figure 2). Similar results were obtained with different cell type in previous studies [4,5].
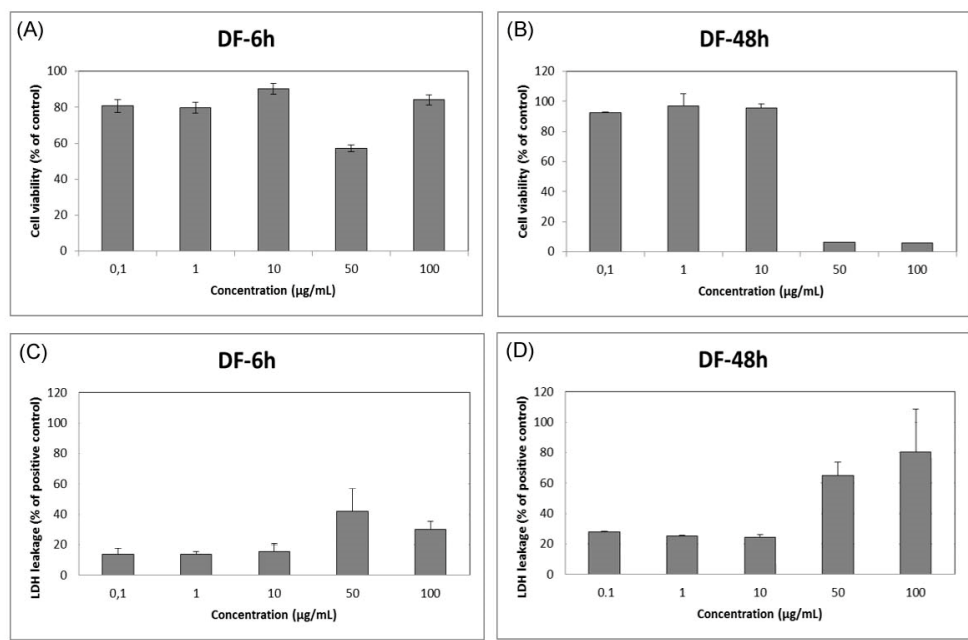

Figure 2. In vitro cytotoxicity assays by (A,B) MTT assay; (C,D) LDH assay.

Real-time impedance measurements demonstrated that cell index values were almost zero in the presence of 50 and $100 \mu \mathrm{g} / \mathrm{mL}$ zinc oxide after $12 \mathrm{~h}$ (Figure 3).

The results showed that $50-100 \mu \mathrm{g} / \mathrm{mL}$ zinc oxide had a higher risk of cellular toxicity compared to lower concentrations under studied experimental conditions.

This study provides the toxic dose levels of bulk zinc oxide to determine its relative safety when used with dermal fibroblasts. Impedance-based high-throughput system seems to be an efficient assay method for evaluating cellular toxicity.

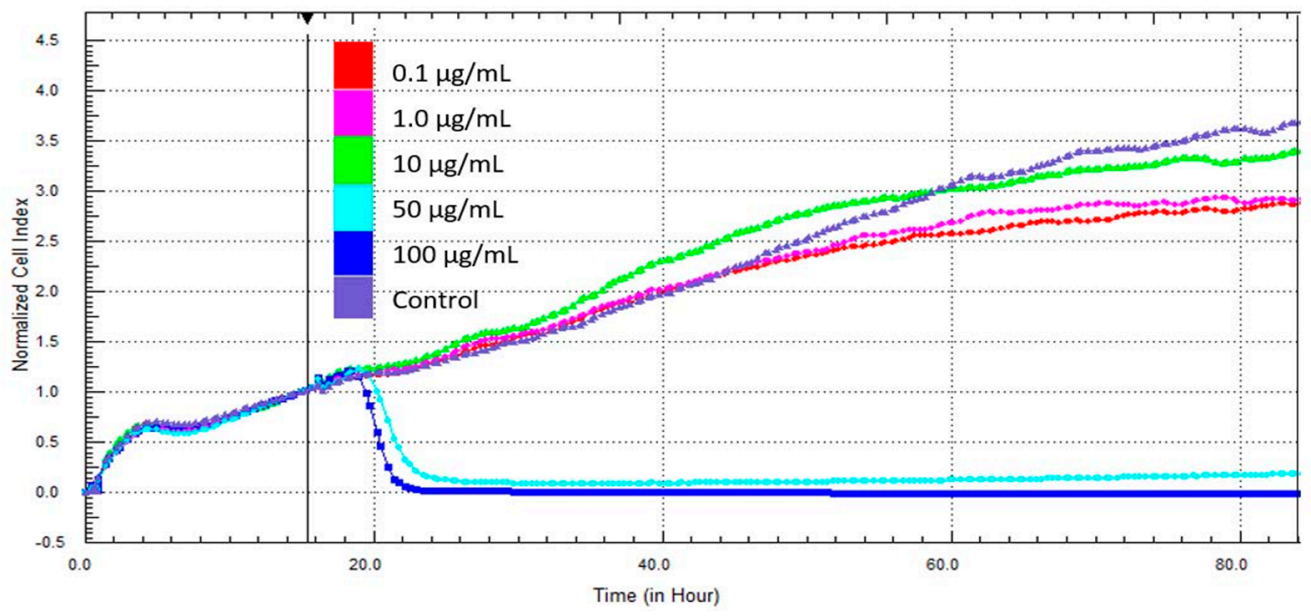

Figure 3. Real-time monitoring of cell responses of $\mathrm{mDF}$.

Acknowledgments: I thank Y. Murat Elçin and A. Eser Elçin very warmly for their advice and support. The data of this work has not been published (or in consideration) elsewhere.

\section{References}

1. Pasquet, J.; Chevalier, Y.; Couval, E.; Bouvier, D.; Noizet, G.; Morlière, C.; Bolzinger, M.A. Antimicrobial activity of zinc oxide particles on five micro-organisms of the Challenge Tests related to their physicochemical properties. Int. J. Pharm. 2014, 460, 92-100, doi:10.1016/j.ijpharm.2013.10.031.

2. Remya, N.S.; Syama, S.; Sabareeswaran, A.; Mohanan, P.V. Investigation of chronic toxicity of hydroxyapatite nanoparticles administered orally for one year in wistar rats. Mater. Sci. Eng. C Mater. Biol. Appl. 2017, 76, 518-527, doi:10.1016/j.msec.2017.03.076. 
3. Şeker, Ş.; Elçin, A.E.; Yumak, T.; Sınağ, A.; Elçin, Y.M. In vitro cytotoxicity of hydrothermally synthesized $\mathrm{ZnO}$ nanoparticles on human periodontal ligament fibroblast and mouse dermal fibroblast cells. Toxicol. In Vitro 2014, 28, 1349-1358. doi:10.1016/j.tiv.2014.06.016.

4. Sahu, D.; Kannan, G.M.; Vijayaraghavan, R.; Anand, T.; Khanum, F. Nanosized zinc oxide induces toxicity in human lung cells. ISRN Toxicol. 2013, 2013, 316075, doi:10.1155/2013/316075.

5. Jeng, H.A.; Swanson, J. Toxicity of metal oxide nanoparticles in mammalian cells. J. Environ. Sci. Health A 2006, 41, 2699-2711, doi:10.1080/1093452060096617.

(C) 2018 by the authors. Licensee MDPI, Basel, Switzerland. This article is an open access article distributed under the terms and conditions of the Creative Commons Attribution (CC BY) license (http://creativecommons.org/licenses/by/4.0/). 